\title{
Rudolf Bultmann as historikus
}

\author{
Willem S Vorster
}

\begin{abstract}
Rudolf Bultmann as historian

The work of Bultmann has had a rather negative reception in South Africa, partly because of the fact that little attention has been paid to his historical interpretation of the New Testament. Unfortunately his name is linked only to his use of philosophical categories in Biblical interpretation. After a few remarks about his early study years and the ideas which framed his later research, the article deals with his work as historian. First he is treated as a historian of religion and then as a literary historian. An attempt is made to understand and describe his views in his contemporary context. The description is done within the framework of the academic context in which he received his training, and the scientific circle in which he performed his academic activities. In conclusion a few remarks of evaluation are made.
\end{abstract}

Durch den Anschluss an Heidegger gelingt es Bultmann, seine Exegese sowohl theologisch (Erfassen des Zusammenhangs) als auch wissenschaftlich (geklärtes Begriffssystem) als auch modern (Seinsverständnis der Menschen nach dem 1. Weltkrieg) sein zu lassen (Berger 1986: 156).

Rudolf Karl Bultmann is op 20 Augustus 1884 in Wiefelstede Oldenburg gebore en is na 'n lang en invloedryke lewe op 30 Julie 1976 te Marburg oorlede. Aan die begin van sy teologiese opleiding te Tübingen het hy reeds sy voorneme te kenne gegee dat hy breër onderlê wil wees as wat van hom verwag word. In 'n brief aan sy ouers skryf hy dat hy ook tuis wil wees in die filosofie, medisyne, geskiedenis en regte (Lemke 1985: 6). Hierdie voorneme het hy uitgevoer soos blyk uit sy korrespondensie met vriende uit hierdie vakgebiede tydens en na sy opleiding. Dit het egter ook meegebring dat hy die teologie nie in afsondering gesien het nie en ook nie beskou het as 'n ivoortoringbedryf nie. Bekommerd oor die feit dat die kerk wetenskaplike resultate van lidmate weerhou, verneem hy in 1904 (as tweedejaarstudent!) van 'n toekomstige patoloog en vriend, Walther Fischer, watter soort lesers ' $n$ populêre boek oor die geskiedenis van godsdiens sou lees. Bultmann was van mening dat 
dit noodsaaklik is om lidmate volledig op hoogte te bring met wat in wetenskaplike kringe aan die gang is. Bultmann wys hom egter verder daarop dat daar baie kritiek op wetenskaplike teologiese navorsing kan wees en noem die Jesusboek van Bousset as voorbeeld. Trouens, as dit die soort werk is wat aangebied word deur navorsers soos Bousset, redeneer hy in ' $n$ volgende brief aan Fischer, beteken dit die einde van die Protestantse kerk (vgl Lemke 1985: 6). Die kerk het die verantwoordelikheid om aan die lidmate meer te bied as etiese kodes. Vir hom lê die volheid van die Christelike godsdiens nie in etiek nie, maar in godsdiens, geloof in God en die koninkryk van God. Hierdie godsdiens mag wel verskil van die oorsprong van 2000 jaar gelede, maar daar bestaan tegelyk 'n historiese band tussen die oorspronge en die hede. Wat verander, is konsepte, nie die mens nie (vgl Lemke 1985: 7). Dit is hierdie verband tussen verlede en hede wat hy as 'n historiese verskynsel beskou en hanteer het, wat van die begin tot die einde van sy loopbaan die middelpunt van sy belangstelling gebly het.

Hy het sy studie in Berlyn voortgesit en gedurende 1906 in Marburg afgesluit. $\mathrm{Na}$ 'n jaar in Oldenburg waar hy Latynonderwyser was, word hy die assistent van professor Heitmüller in Marburg waarna hy eers 'n professoraat in Breslau en daarna in Giessen aanvaar het. In 1921 het hy na Marburg teruggekeer waar hy tot in 1951 'n professoraat in Nuwe Testament beklee het. Met 'n deeglike kennis van die klassieke, en goeie skoling in die teologie, 'n belangstelling in die navorsingsgeskiedenis, 'n baie breë belangstelling in wetenskaplike kennis en 'n intense belangstelling in die mens, het hy die uitdaging van sy tyd bewustelik as erfgenaam van die resultate van die teologiese liberalisme aanvaar. In 1924 skryf hy dat hulle jong teoloë hoegenaamd nie teoloë sou kon word en bly indien hulle nie die erns van radikale waaragtigheid van die liberale teologie geleer het nie. Van die ortodokse univesiteitsteologie het hulle slegs ' $n$ kompromisbedryf geleer wat aanleiding gee tot 'n innerlik-gebroke eksistensie (Bultmann [1924] 1964: 2).

Die rede waarom Bultmann soveel sukses as teoloog in sekere kringe in Europa en Amerika gehad het, naamlik sy doelbewuste en deurdagte en openlike gebruikmaking van 'n filosofiese onderbou vir sy teologiese arbeid, is terselfdertyd die rede waarom hy baie minder invloed in Suid-Afrika gehad het as byvoorbeeld sy tydgenoot Barth. Dit was nie as sodanig Heidegger se invloed op die wyse waarop hy homself teologies uitgedruk het, wat hierdie situasie in die hand gewerk het nie, maar juis die verwyt dat hy filosofies te werk gegaan het - asof alle teologiese uitsprake nie die resultaat van een of ander gereflekteerde of 
ongereflekteerde filosofie is nie. Die gevolg is dat baie van die teologiese probleme wat gedurende die grootste deel van die twintigste eeu in Europa bespreek is en waaraan Bultmann as een van die vooraanstaande Nuwe-Testamentici deelgeneem het, aan baie teoloë en teologie-geïnteresseerdes in Suid-Afrika verbygegaan het. Een sodanige probleem is die historiese verstaan van die Nuwe Testament. Dit is opvallend omdat daar so baie in Suid-Afrikaans-teologiese kringe gemaak word van die historisiteit van die 'feite' van die Christelike geloof en Bultmann die Nuwe Testament juis konsekwent histories probeer verklaar het. Wanneer 'n mens egter die navorsingsgeskiedenis van Suid-Afrikaanse Nuwe-Testamentici se werk nagaan (vgl Borchardt en Vorster 1980 \& 1983), blyk dit dat daar weinig interesse bestaan vir historiese interpretasie van die Nuwe Testament. Hierdie verskynsel, tesame met ander waarop daar nie nou ingegaan kan word nie, verklaar waarskynlik 'n deel van die redes waarom Bultmann grotendeels as persona non grata bekend geraak het. Wat Berger hierbo aanprys as die positiewe resultate in die benadering van Bultmann, het aan baie Suid-Afrikaners verbygegaan omdat daar baie van die onderbou hiervan nooit bekend gemaak is of deeglik verdiskonteer is nie. Ek sal in my behandeling van die tema klem laat val op Bultmann se werk as historikus. Dit sal hopelik meebring dat die vertekende beeld van sy poging om met behulp van kategorieë van die eksistensiefilosofie die evangelie wetenskaplik te bestudeer en sodoende verstaanbaar te maak vir mense wat twee wêreldoorloë deurgemaak het en kinders van die Verligting is, in breër perspektief gesien sal word. Bultmann was 'n veelsydige teoloog, nie slegs ' $n$ vertolker van Heidegger nie.

Die taak van 'n Nuwe-Testamentikus is histories en literêr van aard. Daarom is dit ook nie vreemd dat Bultmann sy lewe aan godsdiens- en literêr-historiese probleme in verband met die vroeë Christendom en hulle geskrifte gewy het nie. In die hieropvolgende behandeling van Bultmann as historikus sal ek na aanleiding van hierdie twee temas aandag skenk aan Bultmann as godsdienshistorikus en as literêrhistorikus.

\section{BULTMANN AS GODSDIENSHISTORIKUS}

Die Positiviste het die mening gehuldig dat daar 'n baie nou verband bestaan tussen die lewe en die werk van 'n skrywer. Wat hy geërf (Ererbtes), geleer (Erlerntes) en beleef het (Erlebtes), verklaar ook wat 'n skrywer skryf (vgl Maren-Grisebach 1977: 12). Sonder om die indruk te 
laat dat ek hierdie standpunt ten volle onderskryf, is dit ook vir my duidelik dat dit vir iemand wat nie op hoogte is met die laat negentiende- en vroeg twintigste-eeuse navorsingsgeskiedenis in Europa nie, baie moeilik sal wees om Bultmann se standpunte oor die geskiedenis van die godsdiens van die oerchristendom en aanverwante sake na behore te verstaan. Joachim Jeremias (1961: 13) skryf daarom tereg dat 'n mens byvoorbeeld Bultmann se standpunt oor die historiese Jesus (kerugmateologie) moeilik kan begryp sonder kennis van die pad wat daartoe gelei het. Vir die doel van hierdie opstel lyk dit my om hierdie rede reeds belangrik om Bultmann se standpunte telkens te kontekstualiseer wanneer dit behandel word. Daarbenewens is dit ook voor-diehand-liggend dat wetenskapsbeoefening 'n sosiale dimensie het (vgl Mouton \& Marais 1985: 9-11). In die geval van Bultmann met sy wye belangstelling, kontak met geleerdes uit ander dissiplines en die aard van Duitse skoolvorming, is dit moeilik om aan die sosiale dimensie van sy wetenskapsbeoefening verby te gaan.

Dit is reeds opgemerk dat Bultmann 'n baie stewige akademiese onderbou gehad het wat saamhang met sy opleiding asook sy belangstelling. Onder die toonaangewende leermeesters wat ' $n$ invloed op hom uitgeoefen het, was daar Karl Müller, 'n kerkhistorikus in Tübingen (vgl Köster 1985: 63vv asook Kümmel 1970), die beroemde godsdienshistorikus en Ou-Testamentikus Herman Gunkel, asook die ewe bekende en invloedryke Adolf von Harnack in Berlyn. In Marburg het die Nuwe-Testamentici Adolf Jülicher en Johannes Weiss, en die dogmatikus Wilhelm Hermann hulle stempel op hom afgedruk. Johannes Weiss het hom voor sy vertrek na Heidelberg geïnspireer om sy dissertasie wat later in 1910 deur Wilhelm Heitmüller aanvaar is oor Der Stil der paulinischen Predigt und die kynisch-stoische Diatribe te skryf. Sy Habilitationsschrift het hy onder Adolf Jülicher in 1912 oor Die Exegese des Theodore van Mopsuestia ingehandig. Hoewel daar reeds aanduidinge van latere ontwikkelinge in die geskrifte van Bultmann oor godsdienshistoriese probleme in hierdie twee geskrifte te sien is, dateer sy belangrikste godsdienshistoriese werk uit die vroeg 1920's en daarna soos ons hieronder sal sien. Dit is egter duidelik dat sy opvattings oor die verhouding tussen etiek en eskatologie in die prediking van Jesus, tussen etiek en godsdiens, die Christelike godsdiens as ' $n$ vorm van sinkretisme, wat uit die Jodedom sowel as die Hellenisme afkomstig is, die ingebedheid van die prediking van Jesus en die teologie van Paulus en Johannes in die kontemporêre godsdiens, die onderskeid tussen Historie en Geschichte en so meer, aanlopers gehad het by en geïnspireer 
is deur sy leermeesters. Sowel die wetenskaplike sirkel as die akademiese klimaat waarin hy sy vak beoefen het, het die aard van sy denke geprikkel.

Ten tye van die voltooiing van Bultmann se studie was die Religionsgeschichtliche Schule wat in Göttingen ontstaan het, reeds goed gevestig. Die bekendste onder hierdie groep jong navorsers wat probeer het om godsdiens as 'n verskynsel te bestudeer en die Christendom binne hierdie verband te plaas, was persone wat latere navorsing oor die Nuwe Testament en die Christendom as godsdienstige verskynsel baie sterk beïnvloed het. Dit sluit persone soos Wilhelm Bousset, Albert Eichhorn, Herman Gunkel, Ernst Troeltsch, Johannes Weiss en William Wrede in. Naas die populêre werk wat hulle verrig het om die onopgeleide kerklidmate in te lig, was hulle ook verantwoordelik vir wetenskaplike geskrifte wat latere navorsing aansienlik sou beïnvloed. Dit blyk nie alleen uit die werke van Bousset en Gunkel nie, maar ook uit dié van mense soos William Wrede wat'n baie sterk invloed op haas alle gebiede van Nuwe-Testamentiese navorsing gehad het (vgl Lüdemann [1986]). Sowel ten opsigte van die prediking van Jesus asook die geskiedenis van die vroeë Christendom in sy verhouding tot die godsdienste wat in daardie tyd bestaan het, het die sogenaamde Religionsgeschichtler op geen onomwonde wyse die standpunt gehuldig dat die Christendom 'n sinkretistiese godsdiens was (vgl Gunkel 1910). Daarnaas was die Religionsgeschichtliche Schule van oortuiging dat die begrippe van die Nuwe Testament nie moreel en intellektueel was nie, maar mities en eskatologies. Hulle het verder gedink dat die sentrum van godsdienstige ervaring die kultus en liturgie was en dat volksvertellinge en mondelinge tradisie die instrumente was met behulp waarvan godsdienskennis oorgelewer is. Godsdienstige ervaring is wesenlik irrasioneel en as 'n mens godsdiens wil verstaan, is dit nodig om die grense van spesifieke godsdienste te oorskry (vgl Köster 1985: 65). Hierdie soort redenasie kan punt vir punt in die geskrifte van Bultmann teruggevind word soos later meer volledig sal blyk.

Aanvanklik het die Religionsgeschichtler veral aandag geskenk aan literêre vorme en die oordrag van godsdienstige kennis. Dit geld ook ten opsigte van die vroeë werk van Bultmann soos sy dissertasie. Daarin het hy die invloed ondersoek wat die Hellenistiese omgewing waarin Paulus hom bevind het, uitgeoefen het op sy denke asook op die vorm waarin hy homself uitgedruk het. Paulus het hom van die uitdrukkingsmeganismes van sy tyd bedien en daarom vertoon sy briewe die styl van populêr-filosofiese diatribe. Bultman se magnum 
opus in hierdie verband is egter Die Geschichte der synoptischen Tradition waarna ek weer sal terugkom. Opmerklik is sy apologetiese redenasies in belang van die Christendom aan die begin van sy loopbaan. In sy vergelyking van die religieuse moment in die intellektualistiese etiek van Epiktetus met dié van die Nuwe Testament betoog hy dat daar 'n aansienlike verskil bestaan, aangesien Epiktetus nie die lewende God geken het nie, onbewus was van die openbaring en gevolglik nie die wil van God kon ken nie (Bultmann 1912). Soos die Religionsgeschichtler het hy die Nuwe Testament nie in die eerste plek immanent bestudeer nie. Deur vergelyking met geskrifte rondom die Nuwe Testament, verstaan 'n mens die Nuwe Testament beter. Hierdie aspek het hy later nog sterker in sy historiese ondersoek uitgebou.

Bultmann se werk word verder gekenmerk deur 'n hermeneutiese benadering waarin hy kennelik aansluiting vind by wetenskapsteorieë van sy tyd (vgl byvoorbeeld Dilthey). Sowel sy eksegetiese as historiese ondersoeke is afgestem op Verstehen en word saamgevat onder die tema: geloof en verstaan (Glauben und Verstehen). Hierdie aspek hang saam met die wyse waarop sy denke veral gedurende die beginjare van sy doseerwerk aan die Universiteit van Marburg ontwikkel het.

Benewens die aansluiting van Bultmann vanaf die Nuwe Testament, in die besonder Paulus, by Augustinus, Luther, Kierkegaard, Graf York von Wartenburg en Jaspers gevind het, is dit ook duidelik dat die neo-Kantiane te Marburg waaronder Dilthey, Hermann, Cohen, Natorp en Hartmann 'n duidelike invloed op sy wetenskapsbeoefening uitgeoefen het. Daar het gedurende hierdie periode 'n lewendige debat tussen teoloë en filosowe bestaan in Marburg (vgl Berger 1986: 130vv). Met die koms van Heidegger na Marburg in 1923 het die situasie nog interessanter geword. Van die begin af tot met Heidegger se terugkeer in 1929 na Freiburg, het Bultmann baie nou met hom saamgewerk in seminare en ook kennelik sterk impulse van hom ontvang ten opsigte van sy verstaansraamwerk. Daar ontwikkel 'n lewendige uitruiling van gedagtes en Bultmann aanvaar die uitdaging om sy begrippe-apparatuur so suiwer moontlik te ontwikkel. Ook tussen hom en Karl Barth ontstaan daar in hierdie tyd 'n baie uitdagende debat waarin die verhouding teologie en filosofie deeglik uitgetrap word.

Ten opsigte van Bultmann se werk as historikus is daar enkele sake wat as gevolg van die bogenoemde interaksie tussen teologie en filosofie kortliks uitgelig moet word. Uit sy lesings oor die teologiese ensiklopedie in die somersemesters van 1926, 1928, 1930, 1933 en 1936 is dit duidelik dat Bultmann in hierdie tyd wetenskapsteoreties baie 
deeglik ingeskerp was en probeer het om sy studente op hierdie vlak baie deeglik in te lig (vgl Bultmann 1984). In sy hantering van die onderwerp is die invloede van die sogenaamde nuwe filosofie voordie-hand-liggend. In die eerste plek is teologie volgens hom 'n wetenskap waarvan die taak anders is as dié van die kerk. In die kerk word daar uit geloof verkondig. As wetenskaplike spreke verkondig teologie egter nie. Daar word op wetenskaplike wyse oor verkondiging en geloof gepraat (bl 160). By die eksistensiefilosofie het hy geleer om die subjek-objek-skema van denke te deurbreek en begrippe baie duidelik te definieer. Die verwerping van die subjek-objek-denke het hy as ' $n$ teologiese noodwendigheid beskou ten opsigte van die spreke 'oor' God. Oor God kan mens alleen praat wanneer jy ook tegelyk oor die mens praat (vgl verder Berger 1986: 134vv). Dit het egter ook ten opsigte van die geskiedskrywing implikasies omdat 'n mens altyd binne die geskiedenis bestaan. Geskiedenis is nie 'n objek wat in die verlede lê nie. Die mens is deel daarvan omdat hy in sy wese 'geskiedenis' is. Hierna moet daar hieronder teruggekom word. Heidegger se seminaar oor die fenomenologie het Bultmann (1984: 199) verder daartoe gebring om te beweer dat egte wetenskap fenomenologies te werk moet gaan deur die fenomene self te laat geld.

Van die nuwe filosofie het Bultmann ook geleer, soos reeds opgemerk, dat begrippe baie deeglik omskryf moet word en verstaanbaar gemaak moet word. Begrippe moet doelmatig en geskik wees. Dit geld ook van die teologie. Hy het hierdie en ander insigte van toepassing gemaak op sy werk as filoloog, historikus en teoloog. Dit kom baie duidelik na vore by sy inskrywings in die Theologisches Wörterbuch zum Neuen Testament. Sy inskrywings is almal duidelik, geskryf in duidelike taal met klem op die kontras, indien enige, met gebruike buite die Nuwe Testament. Dit is tekenend van sy poging om die Nuwe Testament, ook wat die 'begrippe' betref so duidelik moontlik teen (teenoor) die agtergrond te sien van waaruit dit afkomstig is en waarbinne dit gefunksioneer het. In ooreenstemming met die bedoeling van die woordeboek het hy probeer om die voorstellingswêreld van die behandelde 'begrippe' te beskryf. Opmerklik is natuurlik die feit dat hy hierdie kritiese begripsanalise verder gedoen het aan die hand van sy filologies-historiese insigte. In ooreenstemming met sy filologies-historiese opleiding in Duitsland, het hy histories vergelykend sy filologiese arbeid gedoen met die aanname dat betekenis in terme van Begriffsgeschichte omskryf moet word. Sy aanname dat die taalgebruik van die Nuwe Testament deur dié van die Ou Testament en 
by name die Septuagint bepaal is, kom in die meeste van die inskrywings na vore waarvoor hy verantwoordelik was (vgl Vorster 1979: 3vv). Köster (1985: 70) wys tereg daarop dat Bultmann se forte geleë was in die wyse waarop hy die gebruik van die 'begrippe' in die Nuwe Testament met hulle gebruik in die geskrifte daarbuite gekontrasteer het. Hierdie kontrastekening kom ook in ander verbande in sy werk as historikus na vore. Al die voorafgaande insigte en opvattings het sy werk as historikus baie sterk beinvloed. Dit blyk duidelik uit sy navorsing oor Jesus, die oerchristendom en die Evangelie van Johannes.

In sy navorsing oor Jesus en die oerchristendom het Bultmann uitgegaan van die vooronderstellings van die Religionsgeschichtliche Schule, sy insigte oor menswees (Dasein en Existenzverständnis) en geskiedskrywing as 'n dialoog met die verlede. Sowel sy boek oor Jesus as Das Urchristentum im Rahmen der antiken Religionen is pogings om Jesus en die oerchristendom teen die agtergrond van die tyd waarin hulle geleef het, te verstaan en te verduidelik vir mense van die twintigste eeu. Hierin lê die sleutel van Bultmann se werk as historikus. In sy Jesusboek gee hy 'n volledige uiteensetting van sy opvatting oor geskiedenis.

'n Mens kan geskiedenis nie beskou (bekyk) soos wat jy die wêreld rondom jou of die natuur kan bekyk nie. Omdat die mens deur sy eksistensie deel van die geskiedenis is, sê hy met elke woord wat hy oor die geskiedenis uitspreek, ook iets oor homself. Hierdie samehang met die geskiedenis veroorsaak dat hy die geskiedenis nie soos die natuur hanteer nie. In die lig hiervan is geskiedskrywing 'n dialoog met die verlede. ' $n$ Boek oor Jesus is derhalwe meer as ' $n$ oriëntering oor dinge wat in die verlede gebeur het. Die historikus kom derhalwe nie as subjek en bestudeer ' $n$ objek nie, maar stel homself eerder onder die outoriteit van die geskiedenis om deur die geskiedenis onderrig te word. Die objektiwiteit van geskiedskrywing lê nie opgesluit in 'n metode nie, omdat die verlede dan slegs vanuit 'n bepaalde perspektief beskou word, naamlik dié van die skool waartoe die geskiedskrywer behoort. So sou 'n psigologiese beskrywing moeilik die 'wese' van die geskiedenis kan ontsluit, selfs al is psigologiese studies van persone uit die verlede nie as sodanig verkeerd nie. Sy eie aanbieding is ' $n$ persoonlike ontmoeting met die geskiedenis en die leser kry derhalwe Bultmann se ontmoeting en daarom nie 'n 'objektiewe' beskrywing in die gebruiklike sin van die woord nie. Daarbenewens vermy hy alle metahistoriese aspekte en daarom ontbreek alle waarde-oordele oor Jesus en sy prediking. Die boek het te make met die eise van Jesus, dit 
wat hy gewil het en wat daarom as eis van Jesus en deel van sy eksistensie vandag relevant is. Die boek handel nie oor die persoonlikheid van Jesus soos in die lewe-van-Jesus-navorsing nie omdat daar feitlik niks oor sy persoonlikheid gesê kan word nie. Die objek van die studie is gevolglik die werk (optrede) en woorde van Jesus. Dit moet gereproduseer word, want daarin en nie in sy persoonlikheid nie, lê die belang van ' $n$ historiese figuur. Hierdie gedagtes van Jesus moet nie beskou word as 'n sisteem nie. Dit moet eerder as vrae oor hoe ons ons eie bestaan opvat, hanteer word. Die bronne vir die bestudering van die werk en woorde van Jesus is beperk tot die Sinoptiese Evangelies in hulle wordingsgeskiedenis. Alles wat op taal- en saaklike gronde uit die Hellenistiese Christendom afkomstig is, bly buite rekening. Die Johannesevangelie kom ook nie in aanmerking nie. Dat sy optrede en sy uitsprake ten grondslag van die Sinoptiese tradisie lê, kan moeilik ontken word. Dit is egter 'n ander vraag of en in hoeverre die 'gemeente' sy beeld en sy verkondiging getrou en objektief bewaar het (vgl Bultmann 1926: 7-17).

Bultmann se Jesusboek moet as geskiedskrywing in die eerste plek teen hierdie agtergrond beskou word. Dit is nie net die daarstelling van objektiewe 'feite' oor die lewe en woorde van Jesus nie. Dit is sy ontmoeting daarmee in terme van kategorieë soos Dasein, Existenz en Entscheidung. Om dit te bewerkstellig het hy Jesus teen die agtergrond van Jesus se kontemporêre Joodse omgewing probeer beskryf. Hy maak gebruik van die resultate van die navorsing van sy tyd en het nie die bronne oor die Jodedom opnuut histories nagevors nie. Die Jodedom sien dus daar uit soos sy tydgenote hulle voorgestel het voor die ontdekking van Koemraan en die herlewing van die studie van die Apokaliptiek (vgl ook Sanders 1985: 26vv). Sy hele bespreking staan onder die teken van Jesus en Judaïsme asook die vraag na die relasie tussen eskatologie en etiek in die prediking van Jesus. Vir laasgenoemde doel het hy die resultate van Schweitzer en Weiss se Jesusnavorsing ernstig opgeneem, maar tog sy eie pad gegaan. Volgens hom is die aanspraak dat die koninkryk aan die kom is altyd teenwoordig in die wêreld en dwing dit elke persoon tot 'n beslissing net soos wat sy eis tot gehoorsaamheid elke mens dwing om in ooreenstemming met die wil van God 'n beslissing te maak (Bultmann 1926: 38, 76vv). Die hele boek is ' $n$ kontrastekening tussen Jesus en die Jodedom ten einde die eie aard van die optrede en die verkondiging van Jesus toe te lig. Daarbenewens is dit 'n opklaring van alle begrippe wat bespreek word soos die koms van die koninkryk, die wil van God en die ver en nabye 
God. Wat opmerklik is, is die feit dat die begrippe in teenstelling met die Jodedom sowel as die moderne opvattings beskryf word (vgl bv bl 64 en 95-97). Die konstruksie van die prediking van Jesus berus op sy eie navorsing wat neerslag gevind het in sy boek oor die geskiedenis van die Sinoptiese tradisie.

Die beskrywing van die optrede van Jesus word insgelyks teen die agtergrond van die Jodedom in Palestina gedoen. Ook hier geskied dit interpreterend, soos blyk uit die opmerkings oor Johannes se doop en Jesus se verhouding tot Johannes. Volgens Bultmann (1926: 25) het Jesus aan die Johannessekte behoort en was sowel die Johannes- as die Jesussekte messiaans. Anders as baie van sy tydgenote het hy nie gedink dat Jesus Homself as Messias beskou het tydens sy aardse lewe nie (bl 12), maar hy beskou Jesus tog as iemand wat as messiaanse oproermaker gekruisig is (bl 28). Hy behandel Jesus as Jood en beskou hom as 'n Joodse profeet en gevolglik as deel van die geskiedenis van die Jodedom.

Die kern van Bultmann se opvatting oor Jesusnavorsing is reeds in 'n neutedop in hierdie klein Jesusboekie saamgevat. Dit is die idee dat die objek van die geskiedskrywing oor Jesus en die oerchristendom die dinge is wat hulle gedoen het en gesê (geleer) het en nie die bestudering van persoonlikhede nie. Die latere debatte oor die plek van die 'historiese' Jesus en die aard van die geloof van die oerchristendom het reeds hier sy aanloop. In terme van kontemporêre geskiedskrywing in Europa sluit Bultmann in 'n sekere sin aan by die filologies-kritiese skool van Ranke. Soos Ranke het hy waarskynlik onder invloed van Dilthey hermeneuties te werk gegaan. Daar is egter ook opvallende verskille omdat hy nie geïnteresseerd was om die 'naakte feite' daar te stel nie. In aansluiting by die positivisme is sy geskiedskrywing soos sy taal- en literatuurbeskouing evolusionisties van aard. Die invloede van die fenomenologie kan ook nie misgekyk word nie. Uiteindelik is dit egter opvallend dat hy die klem laat val het op die feit dat die historikus die verlede deur die bril van die hede sien. Daarin verskil hy totaal en al van die benadering van Ranke en ander na hom. Dit herinner aan sy Italiaanse tydgenoot Benedetto Croce wat in sy Zur Theorie und Geschichte der Historiographie (1915) betoog het dat historiese kennis saamhang met die soort vrae wat daar gevra word en '... dat die geskiedskrywer die verlede deur die spieël van die hede sien ...' (vgl Van Jaarsveld 1983: 15). Bultmann is uiteraard hierin deur sy kontak met Heidegger beïnloed.

In sy boek Das Urchristentum gaan hy basies dieselfde te werk. Hier 
is die fenomeen wat hy beskryf, egter verskillend en die konteks waarbinne hy dit beskryf, ook nie dieselfde nie. Die doel van die boek is om die oerchristendom in die historiese samehange waaruit dit ontstaan het, te beskryf. Van apologetiese oogmerke soos destyds in sy dissertasie is daar geen sprake meer nie. Dit is trouens, volgens hom, nie die taak van die historikus om die waarheid van die Christendom aan te toon nie. Die historikus kan slegs die verskillende moontlike maniere waarop die mens se eksistensie verstaan word, toelig en daardeur die leser help om tot 'n beslissing te kom oor sy eie interpretasie van bestaan: tua res agitur. Ook in hierdie boek maak hy gebruik van bestaande navorsing oor die verskillende aspekte wat hy behandel (vgl literatuur in Bultmann 1949: 249) sonder om self die onderskeie onderwerpe en godsdienste wat ter sprake kom, histories te ondersoek. Sy taak sien hy as interpretasie van bestaande resultate om sodoende die Existenzverständnis van die oerchristendom as moontlikheid vir die verstaan van menslike eksistensie toe te lig (Bultmann 1949: 7-8).

Omdat die bakermat van die oerchristendom die so genoemde 'laat-Joodse' godsdiens is wat uit die Ou-Testamentiese Joodse godsdiens ontwikkel het, is dit noodsaaklik om die Ou-Testamentiese erfenis na te gaan. Daarnaas moet die oerchristendom egter ook in verband met die Joodse godsdiens ten tye van die ontstaan van die Christendom gesien word. Om egter die sinkretistiese eie aard van die oerchristelike godsdiens tot sy reg te laat kom, skenk hy ook in navolging van sy leermeester Heitmüller aandag aan die Griekse en Hellenistiese godsdienstige erfenis van die oerchristendom. Ten slotte gee hy 'n beskrywing van die oerchristendom as 'n sinkretistiese fenomeen. Opvallend is die feit dat hy die prediking van Jesus onder die godsdiens van die Jodedom ten tye van Jesus behandel (vgl Bultmann 1949: 76vv en 93vv) en nie onder die godsdiens van die oerchristendom nie. Hieroor later meer.

Sy taak as godsdienshistorikus was derhalwe tweërlei. Aan die een kant het hy die godsdienstige oortuigings van die oerchristendom binne sy tydshistoriese konteks as godsdienstige fenomeen beskryf. Daarnaas het hy dit gedoen as teoloog om die moontlikheid van 'n besondere verstaan van eksistensie ( $\mathrm{d}$ i die oerchristelike) toe te lig.

Een van die aspekte van die godsdienshistoriese benadering van Bultmann wat nog nie in hierdie opstel aandag gekry het nie en wat van weselike belang is, onder andere omdat dit ' $n$ belangrike kenteoretiese 
probleem is, is die kwessie van teologiese taalgebruik en by name die teologiese taalgebruik van die Nuwe Testament.

Daar is veral twee standpunte van Bultmann naas sy eksistensiële interpretasie wat die teologiese wêreld in beroering gebring het. Dit was sy sogenaamde ontmitologisering van die Nuwe Testament en sy standpunt oor die sogenoemde historiese Jesus.

Dit is reeds verskeie kere opgemerk dat Bultmann die Nuwe Testament vir die moderne mens verstaanbaar probeer maak het. In hierdie verband het hy erns gemaak met die feit dat die spreke van die Nuwe Testament oor God en oor Jesus mitologies van aard is. Die wêreldbeeld van die Nuwe Testament is trouens ' $n$ mitiese wêreldbeeld. Dit bestaan uit drie dele. In die middel is die aarde. Aan die bokant is die hemel, die woonplek van God en onder die aarde is die onderwêreld, die hel. Die aarde is die plek waar die bonatuurlike magte hulle mag uitoefen waaraan die mens onderworpe is. Die beeld van die geskiedenis van die heil van die mens is in hierdie mitologiese voorstellings ingebed. Hierdie voorstellings wat vir die moderne mens onaanvaarbaar is, omdat hy 'n ander wêreldbeeld het wat op moderne wetenskaplike navorsing gebaseer is, kan maklik teruggevoer word na die mitologieë van die Joodse apokaliptiek en tydshistoriese voorstellings. Daar is niks spesifiek Christeliks aan hierdie voorstellings nie. Vir die moderne mens wie se voorstellingswêreld deur wetenskaplike navorsing gevorm is, is hierdie mitologiese denkvorme totaal onaanvaarbaar en daarom moet dit herinterpreteer word. Dit is nie alleen van toepassing op die wêreldbeeld van die Nuwe Testament nie. Dit geld alle mitiese taalgebruik, insluitend versoening, plaasvervangende offerhande en die opstanding (Bultmann 1960: 15-20). Die oplossing lê egter nie in 'n seleksie van materiaal nie. Dit lê daarin dat die voorstellingswêreld van die Nuwe Testament antropologies, eksistensiaal geïterpreteer word (Bultmann 1960: 22vv). Hierby moet in ag geneem word dat Bultmann teologie as antropologie voorstel omdat teologiese uitsprake vir hom uitsprake oor eksistensie is. Die God van die Christelike openbaring is vir hom die God wat die vrae oor eksistensie sinvol op dreef bring (Bultmann 1960: 126).

Dit is nie hier die plek om op die reaksie wat hierdie probleemstelling uitgelok het, in te gaan nie (vgl Bartsch 1960). Die probleem is kenteoreties, histories en linguisties van aard. Vir die realiste is die spreke oor God en Jesus in die Nuwe Testament geen probleem nie. Die Nuwe Testament word beskou as 'n venster waardeur die werklikheid gesien kan word. Dit is egter 'n ernstige linguistiese en literatuurteo- 
retiese probleem (vgl Lategan en Vorster 1985). Wanneer die kwessie van verwysing en metafisiese of metahistoriese taalgebruik egter aan die orde gestel word, is dit 'n ander saak. Bultmann het in sy godsdienshistoriese bestudering van die Nuwe Testament baie gou teen hierdie probleem gestuit. Ten einde die historiese karakter van die Nuwe Testament ernstig op te neem en daarmee in dialoog te gaan, dit wil sê histories te verstaan, het Bultmann sy ontmitologiseringsprogram voorgestel.

'n Ander interessante historiese interpretasieprobleem wat aanleiding gegee het tot intensiewe debat, is Bultmann se beskouing dat die geskiedenis van Jesus in die verlengstuk van die Jodedom lê. Jesus se geskiedenis behoort tot die geskiedenis van die Jodedom en nie tot die geskiedenis van die Christendom nie. Hy was 'n Joodse profeet en sy verkondiging moet beskou word as vooronderstelling vir die teologie van die oerchristendom. Die geskiedenis van die Christelike godsdiens begin met Pase, die opstanding. Die Christelike godsdiens en by name die Christelike geloof het nie bestaan voordat daar nie 'n Christelike kerugma was wat verkondig het dat Jesus Christus, die Gekruisigde en Opgestane, God se eskatologiese daad van redding was nie (vgl Bultmann 1980: 1vv). Daarmee staan ons midde in die probleem van die sogenaamde historiese Jesus wat Jeremias (1961: 12) tereg in verband bring met die vraag of die historiese Jesus en sy verkondiging van betekenis is vir die Christelike geloof.

Daar is reeds hierbo opgemerk dat Bultmann erns gemaak het met die navorsingsgeskiedenis. Hy het sy werk as voortsetting van die kritiese wetenskapsbeoefening gesien en verrig. Ook in verband met die historiese Jesus-problematiek moet 'n mens sy standpunte as historikus teen die agtergrond van 'n debat sien wat reeds by Hermann Samuel Reimarus in 1778 begin. Volgens Reimarus het Jesus nie sy doel bereik nie, soos blyk uit sy uitroep aan die kruis. Sy dissipels, wat nie kans gesien het om om te draai op die pad wat hulle geloop het nie, het sy lyk gesteel en die boodskap van sy wederkoms en opstanding verdig (vgl Schweitzer 1966: 56 vv en Jeremias 1961: 13). Dit het aanleiding gegee tot 'n stortvloed van lewes van Jesus. Vir die rasionaliste was hy 'n moraalprediker en vir die idealiste die beste voorbeeld van humaniteit. Die estetici het hom as ' $n$ woordkunstenaar beskou en die sosialiste as 'n vriend van die armes en 'n sosiale hervormer; wensbeelde, soos Jeremias (1961: 14) opmerk.

In 1982 het Martin Kähler in sy geskrif Der sogenannte historische Jesus und der geschichtliche, biblische Christus 'n skerp onderskeid begin maak 
tussen 'Jesus' en 'Christus' en historisch en geschichtlich. Jesus was die man van Nasaret en Christus die Heiland wat die kerk verkondig het. Historisch verwys na die 'reine feite' van die verlede, dit wat gebeur het en gesê is. Geschichtlich, daarenteen, verwys na dit wat blywende betekenis het. Volgens hom is dit onmoontlik om oor die 'naakte feite' in die lewe van Jesus enigiets te sê. Die bronne laat dit nie toe nie. Wat wel van belang is, is die verkondigde Christus wat in die Nuwe Testament voorhande lê. Dit het die soeke na die lewe van Jesus vir eers tot stilstand gebring omdat daar al hoe meer besef is dat dit onmoontlik is om ' $n$ betroubare beeld van die lewe van die Jesus wat op aarde geleef het, vas te stel. Dit is by hierdie visie oor die aard van die NuweTestamentiese geskrifte en die probleme van historiese rekonstruksie waarby Bultmann aangesluit het met sy kerugmateologie. Dit het weer later daartoe aanleiding gegee dat sy studente uit vrees dat sy standpunt tot dosetisme sal ly, die lewe-van-Jesus-ondersoek opnuut aan die orde gestel het (vgl Käsemann 1954 en Robinson 1983).

Vir Bultmann het die probleem twee vrae behels: Wat is die historiese kontinuïteit tussen die historiese Jesus en die oerchristelike kerugma? en wat is die saaklike verhouding tussen die twee? Ten opsigte van die eerste vraag is dit duidelik dat die kerugma die historiese Jesus vooronderstel. In hom het sy aanhangers op grond van hulle geloof aan die opstanding die Messias (komende Seun van die mens) en deur God verhoogde Here (kúrios) gesien. Hy wys uitdruklik daarop (1965: 8) dat daar volgens hom 'n historiese kontinuïteit bestaan tussen die historiese Jesus en die kerugmatiese Christus omdat albei historiese fenomene is. Dat daar' $n$ verskil bestaan tussen die historiese Jesus en die Christus van die kerugma, is 'n ander saak. Hierin het Jeremias en ander, hom totaal en al verkeerd begryp omdat hulle van mening was dat hy die historiese kontinuilteit tussen die historiese Jesus en die verkondiging oor Christus ontken. Die 'dat' (Dass) van sy historisiteit kan dus as vooronderstelling aanvaar word, maar die 'hoe' en 'wat' (Wie en Was) is 'n probleem omdat die 'dat' nie sonder meer 'n saaklike kontinuïteit vooronderstel nie. Hy wys daarop dat Paulus en Johannes reeds slegs met die 'dat' werk en nie byvoorbeeld die verkondiging van Jesus bloot herhaal nie. Daarom is die eintlike vraag: Is die historiese Jesus met die Christus van die kerugma identies? Dit beantwoord Bultmann (1965: 27) met die baie skerp geformuleerde sin: 'An den im Kerugma präsenten Christus glauben, ist der Sinn des Osterglaubens.' Historiese navorsing slaag nie daarin om die saaklike kontinuïteit aan te toon nie. 
In sy antwoord op die kritiek wat uit alle oorde oor sy standpunte uitgespreek is, het Bultmann (1965: 8) volgehou met sy bewering dat die historiese Jesus-navorsing se resultate nie van belang is vir die Christelike geloof nie, dat Jesus nie 'n Christen kon gewees het nie en ook dat sy lewe en werk tot die Joodse godsdiens behoort. Hierin het hy probeer om binne sy verstaansraamwerk konsekwent histories te redeneer.

Dat Bultmann binne die denkraamwerk van die Religionsgeschichtliche Schule sy taak as historikus verrig het, blyk verder uit sy publikasies oor die godsdienshistoriese agtergrond van die Johannesevangelie. Aan die begin van die 1920's het hy die aanvoorwerk vir sy kommentaar op die Evangelie van Johannes begin doen. Die resultate is in drie baie belangrike artikels verwerk, waarvan veral die 1923- en 1925-artikels onder sy godsdienshistoriese werk van belang is. Die laaste artikel met die titel 'Untersuchungen zum Johannesevangelium' handel oor die 'begrip' waarheid en die uitdrukking niemand het God nog ooit gesien nie. Vir die doel van hierdie artikel sal daar net aan die eerste twee artikels aandag geskenk word.

In die feesbundel vir Herman Gunkel lewer hy in 1923 ' $n$ bydrae oor 'Der religionsgeschichtliche Hintergrund des Prologs' (vgl Bultmann [1923] 1967: 10-35). Hy probeer deur 'n vergelyking tussen die proloog van Johannes, Joodse wysheidspekulasie en navorsing van veral Reitzenstein oor Manigese en Mandese spekulasie, aantoon dat daar 'n gnostiese verlossingsmite ten grondslag van die proloog sou lê. Dit sal verklaar waarom die skrywer van die proloog sou beweer dat die preëksistente Jesus na die aarde gekom het, maar dat sy eiendom hom nie herken het nie. In die opstel van 1925 oor 'Die Bedeutung der neuerschlossenen mandäischen und manichäischen Quellen für das Verständnis des Johannesevangeliums' maak hy gebruik van die tekste wat Lidzbarski vertaal en uitgelê het om die sogenaamde gnostiese verlossersmite te rekonstrueer aan die hand van die hele Evangelie van Johannes. Hy was deeglik bewus van die feit dat hierdie Mandese en Manigese bronne baie jonger is as die Evangelie van Johannes, maar het tog betoog dat die verlossingsmite daaragter baie ouer is as hierdie geskrifte (vgl Bultmann [1923] 1967: 97 asook Bultmann [1940] 1964; vgl egter Colpe 1961).

Bultmann se doel met die artikel is om die raaisel van die plek van die Johannesevangelie in die ontwikkeling van die oerchristendom te probeer vasstel. Die Evangelie pas nie in die Palestynse Christendom soos deur die Sinoptiese Evangelies voorgestel nie en ook nie in die 
Hellenistiese Christendom soos ons dit by Paulus leer ken nie. Dit kan ook nie in verband met die Joods-Hellenistiese Christendom gebring word wat in 1 Klemens, Hermas, Barnabas of Hebreërs aangetref word nie (vgl Bultmann [1967]: 55vv). Na aanleiding van sy rekonstruksie van die geskiedenis van die verlossingsmite en die geskiedenis van die Mandeërs wat hy as doopsekte terugvoer tot by Johannes die Doper, konstrueer hy ' $n$ ontwikkelingslyn in die geskiedenis van die oerchristendom wat op Johannes die Doper teruggaan en ouer is as die vorm van Christendom wat in die Sinoptiese tradisie teruggevind word. Hierdie vorm van Palestynse Joods-Christendom sou meer vatbaar gewees het vir Hellenisering as dié van die oergemeente in Jerusalem en sou derhalwe ook die brug kon vorm tussen die Palestynse en Hellenistiese Christendom. Daarmee moet die voorstelling van Bousset en Heitmüller wat slegs tussen die Palestynse en Hellenistiese Christendom onderskei het, gewysig word. Volgens hierdie konstruksie en Bultmann het die Palestynse Christendom ook reeds vanaf die begin 'n sterk diversiteit vertoon (vgl Bultmann [1923] 1967: 101vv). Hy wys daarop dat daar egter veel meer navorsing gedoen moet word oor die vroeë Christendom in Sirië waar hy glo die Evangelie van Johannes sy oorsprong het en dat die bron wat Johannes vir sy toesprake gebruik het, gerekonstrueer moet word. Albei hierdie sake het in latere navorsing aandag gekry. Na die ontdekking van die gnostiese biblioteek van Nag Hammadi het die moontlikheid van geskrewe bronne wat ten grondslag van die Johannese toesprake as openbaringsredes lê, groter geword en dit is moontlik dat hierdie hipotese van Bultmann weer sterker op die voorgrond sal tree (vgl Köster 1985: 68).

Dit is uiteraard onmoontlik om op die detail van alle godsdienshistoriese interpretasies van Bultmann in te gaan. Desondanks is dit duidelik dat hy sy interpretasie van die Nuwe Testament baie deeglik onderbou het met godsdienshistoriese materiaal ten einde ' $n$ betroubare tydshistoriese en godsdienshistoriese konteks waarbinne die Nuwe Testament geïnterpreteer moet word, te konstrueer. Daardeur het hy verskeie van sy studente gemotiveer om detailsake, veral wat die gnostiek betref, te ondersoek en talle van sy tydgenote gedwing om indringend navorsing te doen oor talle sake wat die Nuwe Testament raak. Wat eersgenoemde betref, wys Köster (1985: 67) op die volgende dissertasies van godsdienshistoriese aard wat in Marburg onder hom geskryf is: Heinrich Schlier, Religionsgeschichtliche Untersuchungen zu den Ignatiusbriefen, Ernst Käsemann, Leib und Leib Christi, Günther Bornkamm, Mythos und Legende in den apokryphen Thomasakten en ook 
die beroemde boek van Hans Jonas, Gnosis und spätantiker Geist. Wat die belang van sy werk vir sy kollegas betref, lewer die lewendige debatte oor sy standpunte getuienis van sy invloed.

Omdat die Religionsgeschichtliche Schule, soos ek hierbo opgemerk het, aanvanklik veral geïnteresseerd was in literêre vorme en die oordrag van godsdienstige kennis, hou baie van hulle werk verband met literêr-historiese problematiek. In hierdie verband het Bultmann 'n deurslaggewende rol in die Nuwe-Testamentiese wetenskap gespeel.

\section{BULTMANN AS LITERÊR-HISTORIKUS}

In die tweede uitgawe van Die Religion in Geschichte und Gegenwart het Bultmann saam met Gunkel die inskrywing oor 'Biblische Literaturgeschichte' behartig. Hy was verantwoordelik vir die dele wat gehandel het oor metodologiese en wetenskapshistoriese aanmerkings oor literatuurgeskiedenis asook die gedeelte oor die Nuwe Testament (vgl Bultmann 1929: kol 1675-1677 en 1680-1682). Die objek van ondersoek van die literatuurgeskiedenis is volgens hom die literatuurerfenis van 'n bepaalde epog, volks-, kultuur- of religieuse gemeenskap. Die metode waarvolgens dit ondersoek word, is die historiese metode. Die ontstaanstyd, ontstaansomstandighede en die literêre verhouding tussen die verskillende dokumente word bestudeer. Literatuurgeskiedenis is ' $n$ hulpwetenskap by die historiese navorsing oor ' $n$ bepaalde gemeenskap wat uiteraard nie soos literatuurgeskiedenis beperk is tot die historiese bestudering van literêre bronne nie.

Literatuurgeskiedenis word volgens Bultmann ook nog in 'n engere sin gebruik. Dit het te doen met literatuur as 'n lewensuiting van 'n bepaalde gemeenskap soos byvoorbeeld staatslewe, ekonomie, kuns en wetenskap wat indirek uit die dokumente gerekonstrueer moet word. In hierdie verband is nie die wat wat gesê word van belang nie, maar juis hoe dit gesê word, dit wil sê die vorme. Bepaalde sake word in geykte vorme uitgedruk. Daarbenewens het vorme hulle eie 'wette' en daarom is die bestudering daarvan wesenlik. Literatuurgeskiedenis het uiteraard ook betrekking op skriftelike sowel as mondelinge bronne. Die bestudering van hierdie pre-literêre bronne en die vorme waarin mondelinge bronne bebruik is, is ingesluit in die literatuurgeskiedenis. Verder moet die geskiedenis van die literêre vorme (Gattungen) in samehang met die lewe waaruit dit opkom, aangebied word en die persone wat daarby betrokke is, moet beoordeel word.

Wat die Nuwe Testament betref, het literatuurgeskiedenis te make 
met die histories-kritiese bestudering van die geskrifte in hulle geskrewe en pre-literêre vorm in die lig van die tyd en die omstandighede waarin dit ontstaan het. Literatuurgeskiedenis van die Nuwe Testament het derhalwe betrekking op die dokumente van 'n godsdienstige gemeenskap, of liewer gemeenskappe, in die lig van die verspreiding van die Christendom. Dit is beperk tot die geskiedenis van die boeke wat in die kanon opgeneem is, maar sluit ook hulle wording in. Aangesien die geskrifte waaroor dit hier handel, nie die produkte van literêre aktiwiteit is nie en eerder in verband met die kultus- en sendingaktiwiteite van die gemeente gebring moet word, moet hulle Sitz im Leben (sosiologiese lewensituasie) hiermee in verband gebring word. Dit sluit prediking en paranese in die gemeentelewe in asook apologie na buite. Vanweë die konteks waarbinne die Nuwe-Testamentiese literatuur ontstaan het, behoort dit tot die Joodse literatuurgeskiedenis (vgl die dele waaruit die Sinoptiese Evangelies opgebou is, apokaliptiese materiaal, geskiedskrywing, paranese, gebede en liedere ens) sowel as die Hellenistiese literatuurgeskiedenis (vgl wondervertellings, redes of toesprake in die Johannesevangelie, briewe en die dele wat ooreenkoms met die Stoïsynse diatribe gebring kan word). Hieruit blyk dit ook dat hy histories-vergelykend te werk gaan.

Die rol wat die religionsgeschtliche benadering van sy tyd, die opvattings oor literêre afhanklikheid ten opsigte van die evangelies onderling, die filologies-historiese taalkunde, die histories-vergelykende literatuurkunde en die positivisme in die denke van Bultmann as literêr-historikus gespeel het, is onmiskenbaar in die kort samevatting van sy standpunte hierbo. Dit moet egter verder uitgebou word.

Soos ons hierbo gesien het, het Bultmann met die nodige korreksies by Bousset en Heitmüller se konstruksie van die godsdiens van die oerchristendom aangesluit (vgl Bultmann 1966: 11vv). Hiervolgens moet daar rekening gehou word met sowel Palestynse as Hellenistiese ontwikkelingslyne in die literatuur van die Nuwe Testament. Ten opsigte van die evangelies het dit beteken dat daar onder die finale geskrewe laag in die teks wat in Grieks geskryf is, 'n Aramese laag veronderstel kan word wat ò in geskrewe vorm kon bestaan het en dus as bron deur die 'redaktors' van die evangelies gebruik kon gewees het, ò in mondelinge vorm oorgelewer is. Dit is uiteraard 'bevestig' deur die stylkritiese ondersoeke van die vroeëre Literarkritik wie se resultate hy in die algemeen gesproke aanvaar het. Vooronderstelling is die tweebronne-hipotese waarvolgens Markus die oudste geskrewe evangelie is waaroor ons beskik en dat Matteus en Lukas literêr afhanklik is 
van Markus en 'n versameling van Jesus-uitsprake, genaamd $Q$ (Quelle). Volgens hierdie benadering het literêre kritiek te make met die afsondering van bronne wat skrywers gebruik het in die samestelling van hulle geskrifte.

In aansluiting by die resultate van die Literarkritik is dit die taak van die literêr-historikus om die literêre geskiedenis wat agter die geskrewe teks lê, te probeer vasstel. Vir dié doel is die bestudering van vorme (Gattungen), byvoorbeeld gelykenisse of strydgesprekke en so meer, en die wette wat eie is aan elke vorm, dit wil sê Formgeschichte veral nuttig. Vanuit ' $n$ bepaalde hoek bekyk, is literatuurgeskiedenis (Literaturgeschichte) derhalwe Formgeschichte. Die benadering is in dié sin diakronies dat dit die geskiedenis van die oorlewering van ' $n$ bepaalde vorm in al sy oorleweringsfases probeer nagaan. Daar kom egter nog 'n aspek by, naamlik die vergelyking van Gattungen met soortgelyke Gattungen in ander literatuur, kontemporêr en vroeër. Hierin is Formgeschichte histories vergelykend van aard en gaan dit sowel sin- as diakronies te werk. In sy eie bydrae oor die Sinoptiese tradisie kon Bultmann sterk terugval op die werk van tydgenote oor die strydgesprekke, lydensgeskiedenis van Jesus, die vertelstyl van die evangelies, wondervertellings en die opstandingsvertellings (vgl Bultmann 1966 en 1970).

Bultmann het in verband met die literatuurgeskiedenis van die Sinoptiese tradisie ' $\mathrm{n}$ baie groot bydrae gelewer. Sedert die verskyning van Die Geschichte der synoptischen Tradition in 1921 (vgl ook Bultmann 1966) het hierdie werk ten spyte van ander soortgelyke werke, soos byvoorbeeld dié van Dibelius, die toneel oorheers. Nie alleen is sy keuse ten opsigte van die verskillende benaminge van Gattungen verkies bo dié van Dibelius (vgl Hahn 1985: 448) nie, maar daar is ook besef dat sy analitiese metode waarskynlik meer om die lyf het as Dibelius se konstruktiewe metode ten opsigte van Sitz im Leben. Bultmann (1970: 6) het sy werk nie in teenstelling met dié van Dibelius beskou nie. Hy het dit eerder as aanvullend gesien.

Die doel van die Formgeschichte is volgens Bultmann (1970: 7) om die oorspronklike vorm van elke vertelde eenheid vas te stel om sodoende die geskiedenis van die tradisie te kan beskryf. Dit bevestig die idee dat literatuurgeskiedenis in hierdie verband die taak van literatuurargeologie het. Daar moet agter die teks deur al die lae van die oorlewering geworstel word.

Op grond van die feit dat literatuurgeskiedenis ook in verband met die lewe van die groep wie se literatuur dit is, gebring behoort te word, is die sosiologiese begrip Sitz im Leben deur Bultmann in navolging van 
Gunkel en ander gebruik. Hierdie begrip wat in die latere navorsing teenstrydig met die teorie van die religionsgeschichtliche benadering in 'n spekulasiebegrip oor die sogenaamde historiese situasie ontwikkel het, is by Bultmann (1970: 4) 'n spesifiek sosiologiese begrip. Dit dui op 'n tipiese situasie of optrede in die lewe van die gemeente en nie op '. . . ein einzelnes historisches Ereignis . . ' nie. Hahn (1985: 448) skep in sy bespreking van Bultmann in hierdie verband verwarring.

Bultmann (1970: 5) is deeglik bewus daarvan dat daar by die formgeschichtliche werk in verband met die geskrifte van die Nuwe Testament ' $n$ hermeneutiese sirkel bestaan. Uit die vorme van literêre oorlewering word daar gevolgtrekkings gemaak oor die motiewe van die gemeenskapslewe waaruit dit ontstaan het. En uit die gemeenskapslewe word die vorme weer verduidelik. Hy wys egter tereg op die noodwendigheid van die hermeneutiese sirkel in hierdie historiese konstruksies.

Die hoofkenmerk van literatuurgeskiedenis, soos Bultmann dit beoefen het, is die feit dat dit nie die literêre geskiedenis van tekste in hulle geheel in vergelyking met ander tekste is nie, maar die geskiedenis van die wording van tekste binne tekste. Hoewel hy in Die Geschichte der synoptischen Tradition aandag skenk aan die drie evangelies as geheeltekste, gaan dit nie om die werk van outeurs in die eintlike sin van die woord nie en word die tekste nie vergelykend in die geskiedenis van die literatuur ingepas nie (vgl Bultmann 1970: $362 \mathrm{vv}$ ). Op grond van sy aanname (1970: 5) saam met sy tydgenote dat die evangelies 'Kleinliteratur' (vgl Schmidt 1923: 101 en Vorster 1984: 6vv) is, kan die evangelies ook nie met ander literatuur uit die tyd vergelyk word nie. As kultuslegendes het die evangelies uit die Christusmite ontwikkel. Godsdienshistoriese aannames bepaal derhalwe ook die manier waarop hy as literêr-historikus die geskiedenis van tekste in hulle geheel behandel. Wat van toepassing is op die Sinoptiese Evangelies, geld ook vir sy standpunt oor die Evangelie van Johannes. Dit is die resultaat van die verwerking van bronne (semeia en redebronne) waarin die gnostiese verlossingsmite ' $n$ rol gespeel het.

'n Mens moet in gedagte hou dat die positivisme die literatuur- en taalkunde-beskouings gedurende hierdie tyd en baie lank daarna in Duitsland oorheers het. Die filologie sowel as die literatuurkunde is bestudeer in hulle wordingsgeskiedenis. Dit is daarom ook nie vreemd dat Bultmann se beskouing as literêr-historikus gekenmerk word deur sy analitiese, analogiese, induktiewe en genetiese benaderingswyse nie (vgl Maren-Grisebach 1977: 10vv). Wat hom veral geïnteresseer het, was 
die wording van die tekste. Daarmee word nie ontken dat hy as literêr-historikus baie belangrike histories-vergelykende werk gedoen het nie. Inteendeel, sy omgang met buite-Bybelse tekste is aanduiding daarvan dat hy juis die Nuwe-Testamentiese geskrifte in 'n breër raam gesien het as die kanon, selfs al het hy die literatuurgeskiedenis beperk tot hierdie geskrifte. Wat wel duidelik is, is die feit dat sy godsdienshistoriese vooronderstellings oor godsdienstige literatuur en die invloed van die wetenskaplike kring waarbinne hy gewerk het, sy definisie van literatuurwetenskap bepaal het (vgl ook Petersen 1980).

\section{EVALUASIE}

In my uiteensetting van die werk van Bultmann as historikus het ek probeer om so min as moontlik evaluerende opmerkings te maak ten einde ' $n$ poging aan te wend om sy werk te verstaan. Die gevaar bestaan by enige evaluasie om anakronisties te werk te gaan. So ' $n$ benadering sou in 'n sekere sin maklik, maar ook tegelyk onregverdig wees. 'n Mens moet besef dat dit vir enige beoordelaar moeilik is om iets of iemand met ' $n$ ander bril as sy eietydse bril te sien. Ons leef immers in 'n tyd waarin daar baie en ander opvattings oor geskiedenis en literatuur op die mark gekom het wat ons eie perspektief bepaal. Vanuit 'n ander godsdienshistoriese perspektief as die religionsgeschichtliche perspektief van die Religionsgeschichtliche Schule en met die inagneming van die ontdekkings van Koemraan en Nag Hammadi, moes sienings oor die godsdiens van die Jodedom in die tyd van Jesus en gnostiek noodwendig aansienlik aangepas word. Wat die taal- en literatuurkunde betref, het daar groot verskuiwings plaasgevind. Om hierdie rede sou dit maklik wees om Bultmann as historikus negatief te beoordeel en sy standpunte op baie punte as agtergehaal te beskou. Dit is egter nie wat ek hier in gedagte het nie.

Die waarde van Bultmann se werk as historikus lê in sy pogings om krities met sy wetenskapsbeoefening om te gaan en bereid te wees om sy standpunte in gesprek te bring. Die debatte wat rondom sy standpunte gevoer is, is legio en die impulse wat hy aan navorsing gegee het, oorweldigend. Die probleme wat hy probeer hanteer het, is probleme wat meesal vandag nog deur teoloë ernstig opgeneem moet word. Die geskiedenis van die oerchristendom is nog nie klaar geskryf nie, die historiese Jesus-probleem nog nie opgelos nie, die verhouding tussen mondelinge en skriftelike oorlewering vra nog om beter insig en die raaisel rondom Johannes se Evangelie is nog op die tafel.

Hoewel Bultmann in Suid-Afrika soos elders daarvan beskuldig is dat 
hy teologie in filosofie laat opgaan het, dat daar 'n tweespalt is tussen Bultmann as historikus en sistematikus (Althaus 1961: 246), omdat hy sy historiese werk met filosofie verbind het (vgl Cullmann 1961: 271), kom 'n mens moeilik weg van die indruk dat hy 'n baie opwindende poging aangewend het om die evangelie vir die moderne mens verstaanbaar te maak. Dat hy sy historiese werk in die kleed van veral Heidegger se filosofiese raamwerk aangebied het, het deeglike gevolge gehad vir sy resultate. Hy was egter in die eerste plek historikus van sy tyd. Die alternatiewe wat vir hom oopgelê het, was nie baie nie. Hy kon sy werk as Nuwe-Testamentikus konsekwent histories gedoen het sonder om 'n poging aan te wend om dit vir die moderne mens te vertaal. Die positiewe sy van so ' $n$ benadering is die vervreemdingseffek wat dit het. Dit lei die moderne mens noodwendig daartoe om sy godsdiens in andersheid te aanvaar omdat hy nie 'n 'Nuwe-Testamentiese Christen' kan wees nie - selfs al wil hy! Hy kon hierdie werk egter soos baie van sy tydgenote met die spekulatiewe filosofie van Heilsgeschichte verbind het of met fundamentalisme. Sou hy die evangelie daardeur meer relevant kon maak as deur sy eie pogings?

Bultmann het die uitdaging van sy tyd in sy eie wetenskaplike kring met die metodes van die dag en met die oog op die kerk op sy eie manier aangepak. Daarvoor was hy geen apologie aan enigiemand in die akademiese wêreld verskuldig nie. Dit is jammer dat daar in Suid-Afrika so min kennis geneem is van Bultmann as historikus. Miskien sou dit ons beter in staat gestel het om met die godsdiens van die Nuwe Testament in aanraking te gekom het. In elk geval sou dit ons versigter gemaak het vir God-is-aan-my-kant-teologie.

Dit is vir my ' $n$ groot eer om hierdie gedagtes in ' $n$ feesbundel ter ere van professor $\mathrm{CH}$ Rautenbach uit te spreek. As filosoof het hy nie gehuiwer om die historiese onderbou van die Christelike godsdiens in 'n moderne kleed te aanvaar nie (vgl Rautenbach 1978). As teoloog het hy die filosofiese en etiese dimensies van die Christelike godsdiens kontemporêr deurdink.

\section{Literatuurverwysings}

ALTHAUS, P 1961. Zur Kritik der heutigen Kerygmatheologie, in Ristow \& Matthiae 1961: 236-265.

BARTSCH, H-W 1960. Kerygma und Mythos: Ein theologisches Gespräch. 4.Aufl. Hamburg: Herber Reich.

BERGER, K 1986. Exegese und Philosophie. Stuttgart: Katholisches Bibelwerk. 
BORCHARDT, CFA EN VORSTER, WS (reds) 1980 \& 1983. South African theological bibliography/ Suid-Afrikaanse teologiese bibliografie, Volumes 1 en 2. Pretoria: Universiteit van Suid-Afrika.

BULTMANN, R 1912. Das religiöse Moment in der ethischen Unterweisung des Epiktet und das Neue Testament. ZNW 13, 97-110 en 177-191.

BULTMANN, R [1923] 1967. Der religionsgeschichtliche Hintergrund des Prologs zum Johannesevangelium, in Bultmann 1967: 10-35.

BULTMANN, R [1924] 1964. Die liberale Theologie und die jüngste theologische Bewegung, in Bultmann, $R$ 1964: 1-25.

BULTMANN, R [1925] 1967. Die Bedeutung der neuerschlossenen mandäischen und manichäischen Quellen für das Verständnis des Johannesevangeliums, in Bultmann 1967: 55-104.

BULTMANN, R 1926. Jesus. Tübingen: Mohr.

BULTMANN, R 1929. Sv 'Literaturgeschichte, Biblische'. RGG 2.Aufl.

BULTMANN, R [1940] 1964. Johanneische Schriften und Gnosis, in Bultmann, R 1964: 230-254.

BULTMANN, R 1949. Das Urchristentum im Rahmen der antiken Religionen. Zürich: Artemis.

BULTMANN, R 1960. Neues Testament und Mythologie: Das Problem der Entmythologisierung der neutestamentlichen Verkündigung, in Bartsch 1960: 15-48.

BULTMANN, R 1964. Glauben und Verstehen: Gesammelte Aufsätze. 5.Aufl. Tübingen: Mohr.

BULTMANN, R 1965. Das Verhältnis der urchristlichen Christusbotschaft zum historischen Jesus. 4.Aufl. Heidelberg: Carl Winter.

BULTMANN, R 1966. Die Erforschung der synoptischen Evangelien. 5.Aufl. Berlin: Alfred Töpelmann.

BULTMANN, R 1967. Exegetica: Aufsätze zur Erforschung des Neuen Testaments. Hrsg von E Dinkler. Tübingen: Mohr.

BULTMANN, R 1970. Die Geschichte der synoptischen Tradition. 8.Aufl. Göttingen: Vandenhoeck.

BULTMANN, R 1980. Theologie des Neuen Testaments. 8.Aufl. Tübingen: Mohr.

BULTMANN, R 1984. Theologische Enzyklopädie. Hrsg van E Jüngel \& $\mathrm{KW}$ Müller. Tübingen: Mohr.

COLPE, C 1961. Die religionsgeschichtliche Schule: Darstellung und Kritik ihres Bildes vom gnostischen Erlösermythus. Göttingen: Vandenhoeck.

CULLMANN, O 1961. Unzeitgemässe Bemerkungen zum 'historischen Jesus' der Bultmannschule, in Ristow \& Matthiae 1961: 266-280.

GUNKEL, H 1910. Zum religionsgeschichtlichen Verständnis des Neuen Testaments. 2. Aufl. Göttingen: Vandenhoeck.

HAHN, F 1985. Die Formgeschichte des Evangeliums: Voraussetzungen, Ausbau und Tragweite. Darmstadt: Wissenschaftliche Buchgesellschaft.

HOBBS, EC (ed) 1985. Bultmann, retrospect and prospect: The centenary symposium at Wellesley. Philadelphia: Fortress.

JEREMIAS, J 1961. Der gegenwärtige Stand der Debatte um das Problem des historischen Jesus, in Ristow \& Matthiae 1961: 12-25.

KÄSEMANN, E 1954. Das Problem des historischen Jesus. ZThK 51, 125-153.

KOSTER, H 1985. Early Christianity from the perspective of the History of Religions: Rudolph Bultmann's contribution, in Hobbs 1985: 59-74.

KÜMMEL, WG 1970. Das Neue Testament: Geschichte der Erforschung seiner Probleme. 2.Aufl. Freiburg: Karl Alber.

LATEGAN, BC \& VORSTER, WS 1985. Text and reality: Aspects of reference in Biblical texts. Philadelphia: Fortress.

LEMKE, AB 1985. Bultmann's papers, in Hobbs 1985: 3-12. 
LÜDEMANN, G [1986]. Die Religionsgeschichtliche Schule: Zum Andenken en Carl Andresen. Ongepubliseerde referaat.

MAREN-GRISEBACH，M 1977. Methoden der Literaturwissenschaft. 6.Aufl. München: Francke.

MOUTON, JC \& MARAIS, HC 1985. Metodologie van die geesteswetenskappe: Basiese begrippe. Pretoria: Raad vir Geesteswetenskaplike Navorsing.

PETERSEN, NR 1980. Literary criticism in Biblical studies, in Spencer, RA (ed) Orientation by disorientation: Studies in literary criticism and Biblical literary criticism. Presented in honor of WA Beardslee, 25-50. Pittsburgh: Pickwick.

RAUTENBACH, $\mathrm{CH}$ 1978. Die toekoms van die kerk in die samelewing - kollig op die sosiaal-etiese, insluitende politieke afmetings van Christelike kerk-bly in Suid-Afrika, in Vorster, WS (ed/red) 1978. Church and society/Kerk en samelewing. Pretoria: Universiteit van Suid-Afrika.

RISTOW, H EN MATTHIAE, K (Hrsg) 1961. Der historische Jesus und der kerygmatische Christus: Beiträge zum Christusverständnis in Forschung und Verkündigung. 2.Aufl. Berlin: Evangelische Verlagsanstalt.

ROBINSON, JM 1983. A new quest of the historical Jesus and other essays. Philadelphia: Fortress.

SANDERS, EP 1985. Jesus and Judaism. Philadelphia: Fortress.

SCHMIDT, KL 1923. Die Stellung der Evangelien in der allgemeinen Literaturgeschichte, in Schmidt, $\mathrm{H}$ (Hrsg), Eucharistērion: Studien zur Religion und Literatur des Alten und Neuen Testaments. H Gunkel-Festschrift, Vol 2, 50-134. Göttingen: Vandenhoeck.

SCHWEITZER, A 1966. Geschichte der Leben-Jesu-Forschung. I. München: Siebenstern.

VAN JAARSVELD, FA 1983. Moderne geskiedskrywing: Opstelle oor ' $n$ nuwe benadering tot geskiedenis. Durban: Butterworth.

VORSTER, WS 1979. Aischunomai en stamverwante woorde. Pretoria: Universiteit van Suid-Afrika.

VORSTER, WS 1984. Der Ort der Gattung Evangelium in der Literaturgeschichte. $V u F$ $1984,2-25$. 